\title{
Dialektika Khilafah dan Politik Kebangsaan dalam Media Publik Siber
}

\author{
Minan Jauhari ${ }^{*}$, Yayan Sakti Suryandaru' ${ }^{2}$, Rahma Sugihartati ${ }^{3}$ \\ UIN Kyai Haji Achmad Siddiq Jember, Indonesia; minanjauhari78@gmail.com \\ 2 Universitas Airlangga Surabaya, Indonesia; yayansaktis@gmail.com \\ 3 Universitas Airlangga Surabaya, Indonesia; rsugihartati@yahoo.com \\ * Correspondence: minanjauhari78@gmail.com
}

Received: 2021-02-03; Accepted: 2021-07-17; Published: 2021-08-21

Abstract: The current article discusses the dialectic of Khilafah (caliphate) and the national political system expressed through two cyber media of two religious communities as the new public spaces, namely the da'wah media of Islam Kaffah community and NU community. The current debate/discourse explains Khilafah (Caliphate), which is an Islamic teaching that must be applied to Muslims. On the other hand, it is understood as a historical fact because it contrasts with the Indonesian national political system. This study is qualitative research with an ethnomethodological method focusing on digital conversation to be analyzed. Such analysis is conducted by displaying texts which show a conversational activity in conveying arguments and ideas about the Khilafah (caliphate) and national political system as the data analysis. The aim is to answer the research question about how the dialectic of Khilafah (caliphate) and national political system is portrayed through the new public spaces (cyber media), whether the dialectic processes that occur produce consensus or instead of trigger conflicts. Furthermore, by using a social perspective that uses the term "Public Space", the current study can illustrate that the dialectical processes displayed through the cyber media of the religious communities contain prolonged clashes and debates about the idea of Khilafah (caliphate). In the two community media studied, the media of Islam Kaffah Community and the media of NU community, the dialectical process tends to create consensus. This is because the narrative of Khilafah (caliphate) and the national political system becomes the subject of conversations, so that it triggers conflicts between religious communities in the virtual space.

Keywords: Caliphate ideology; dialectic; national politics; public cyberspace.

Abstrak: Artikel ini membahas tentang dialektika khilafah dan politik kebangsaan yang diekspresikan melalui dua media komunitas keagamaan siber sebagai ruang publik baru, yaitu media komunitas dakwah Islam kaffah dan media komunitas NU. Perdebatan/ diskursus tentang khilafah ini, satu sisi dipahami sebagai ajaran Islam yang wajib diterapkan bagi umat muslim, namun disisi lain dipahami sebagai fakta sejarah, karena dinilai bertentangan dengan sistem politik kebangsaan Indonesia. Studi ini menggunakan pendekatan kualitatif dengan metode etnometodologi fokus pada analisis percakapan digital, yaitu menempatkan teks yang ditampilkan sebagai aktivitas percakapan dalam menyampaikan argumentasi dan gagasan tentang ide khilafah dan politik kebangsaan sebagai data analisis. Tujuannya agar dapat menjawab pertanyaan studi bagaimana dialektika khilafah dan politik kebangsaan ditampilkan melalui ruang publik baru (media siber), apakah proses dialektika yang terjadi menghasilkan konsensus, atau justru memicu terjadinya konflik. Selanjutnya dengan menggunakan perspektif sosial yaitu "Ruang Publik", studi ini dapat memberikan gambaran bahwa proses dialektika yang ditampilkan melalui media komunitas keagamaan siber menunjukkan adanya benturan dan perdebatan gagasan tentang khilafah yang berkepanjangan, bahkan terhadap dua media komunitas yang sedang dikaji yaitu media komunitas dakwah Islam kaffah dan media komunitas NU cenderung tidak menghasilkan konsensus, yang terjadi narasi khilafah dan politik kebangsaan menjadi bahan percakapan sehingga memicu konflik di antara komunitas keagamaan diruang virtual.

Kata Kunci: Dialektika; Khilafah; Media Publik Siber; Politik Kebangsaan. 


\section{Pendahuluan}

Ekspresi keagamaan yang ditampilkan dalam media publik siber, salah satunya ditandai dengan munculnya kembali ide khilafah dan politik kebangsaan, sehingga menjadi perdebatan/diskursus di antara komunitas keagamaan. Studi ini melihat dua media komunitas keagamaan siber yaitu media komunitas dakwah Islam kaffah dan media komunitas organisasi Nahdlatul Ulama (NU) yang saling berseberangan dan menunjukkan perbedaan pendapat dalam merespon narasi-narasi tentang paham khilafah. Respon yang ditampilkan ini dapat menentukan terhadap sikap ideologi politik dan keagamaan secara terbuka. Dalam konteks ini, sebagian komunitas keagamaan harus memahami khilafah sebagai ajaran Islam yang wajib diterapkan sebagai sistem pemerintahan, namun sebagian lagi menilai bahwa paham khilafah semacam ini sesungguhnya bertentangan dengan sistem politik kebangsaan di Indonesia.

Dalam konteks terjadinya diskursus, perlu atau tidaknya sebuah konsensus bersama dan kriteria dalam sebuah penilaian (hukum, sosial, politik, ekonomi, budaya dan seni), sesungguhnya terjadi perbedaan pandangan di kalangan teoritis. Jurgen Habermas (2015) menganggap perlu adanya konsensus universal yang dilandasi oleh prinsip komunikatif. Berbeda dengan pandangan J.F Lyotard (1984) melihat bahwa ketidakmungkinan adanya konsensus (disensus) dalam sebuah diskursus, sebab di dalam dunia yang dibangun oleh narasi-narasi kecil, harus dilihat dalam bingkai inkomen-surabilitas satu sama lainnya. Sementara John Rawls (1987) juga berpandangan berbeda, menurutnya dalam diskursus melihat adanya konsensus yang tumpang tindih (overlapped consensus). Menurutnya elemen-elemen masyarakat plural, demi menjaga keadilan, seharusnya dicarikan jalan tengahnya.

Sementara fungsi ruang publik baru (media siber) ini dapat disebut sebagai public sphere, ruang diskrusif, dan sebagai saluran bertemunya wacana sehingga dapat tercipta interaksi antar komunitas keagamaan (Dwivedi \& Narula, 2020; Giorgi, 2019; Zakaria, Busro, \& Furqon, 2018). Meski demikian ekspresi yang terjadi dalam diskursus ini ternyata tidak sepenuhnya dapat menghasilkan konsensus, akan tetapi dalam tampilannya banyak ditandai oleh tampilan teks yang berbenturan bahkan benturan paham dalam teks yang ditampilkan juga berpotensi menjadi sumber konflik diantara komunitas keagamaan. Berangkat dari fenomena keagamaan dalam media siber ini, studi memandang perlu dilakukan kajian-kajian secara lebih mendalam khususnya dalam studi social, seiring dengan pemikiran bahwa perkembangan teknologi informasi dan komunikasi dapat menjadikan media siber menjelma sebagai ruang publik baru (Rulli, 2014).

Kementerian Agama RI melalui buku tentang "moderasi agama" diterbitkan oleh Badan Litbang dan Diklat Kemenag RI, menyebutkan pada era disrupsi digital telah mendorong lahirnya kompleksitas masyarakat dalam beragama. Dangkalnya sumber pengetahuan agama menjadi sebab dalam memahami ayat-ayat suci secara tekstual, disertai dengan fanatisme yang berlebihan. Keadaan ini juga dapat mengarah pada munculnya ekslusivisme, ekstremisme, dan bahkan juga terorisme. Sementara, perkembangan teknologi digital disinyalir membuka ruang kebebasan bagi masyarakat dalam mengekspresikan keagamaannya yang memungkin juga bergeser menjadi pendapat publik. Sebagian umat sengaja menggunakan ruang kebebasan digital dengan mempermainkan pesan-pesan Tuhan menjadi pesan pribadi yang sarat dengan kepentingan. Hal inilah kemudian menjadi persoalan yang sangat rentan, apalagi persoalan ini dapat menciptakan konflik yang dapat mengoyak keharmonisan kehidupan bersama (Kementerian Agama RI, 2019).

Terhadap gambaran fenomena keagamaan yang terekspresikan dalam ruang publik baru, studi ini meyakini sebagai penanda atas terjadinya sengkarut hubungan antar komunitas keagamaan. Dalam konteks ini ekspresi keagamaan yang di tampilkan melalui perdebatan khilafah dan politik kebangsaan, mengakibatkan masyarakat siber harus terfragmentasi dalam kelompok-kelompok yang saling berseberangan. Sebagian komunitas menginginkan penerapan syariah Islam secara kaffah melalui sistem khilafah dan menjadi pilihan politik yang harus diperjuangkan, namun sebagian lagi, komunitas keagamaan mainstream di Indonesia seperti Muhammadiyah dan NU, harus menolak (Kontra) terhadap ide khilafah ini, karena dinilai bertentangan dengan sistem politik kebangsaan yang telah disepakati bersama yaitu Negara Kesatuan Republik Indonesia (Fathoni, 2018). Mochamad 
Faizal Rizki menilai bahwa Ide Khilafah ini berbahaya karena secara terstruktur dan sistematis melakukan infiltrasi pemikiran pendirian khilafah serta penolakan terhadap demokrasi, ideologi Pancasila, UUD 1945, NKRI dan Bhinneka Tunggal Ika (Rizki, 2018).

Beberapa studi menyebut bahwa khilafah merupakan salah satu bentuk pemerintahan yang pernah eksis dalam lintasan sejarah dan peradaban umat Islam di dunia. Allah dan rasul-Nya tidak menyebutkan secara langsung model pemerintahan yang harus dibentuk oleh umat Islam. Bahkan setelah rasulullah wafat umat Islam di Madinah saat itu hanya berijtihad sendiri dalam menentukan siapa yang akan menggantikan jabatan Nabi Muhammad sebagai kepala negara Madinah termasuk jabatan spiritual non kerasulan yang diembannya (Zain, 2019), karena itu banyak kalangan menyebut bahwa menjadikannya sebagai system Negara di Indonesia dianggap tidak relevan. Disebutkan oleh Alaika M. Bagus Kurnia (2018) bahwa negara yang didiami oleh penduduk yang majemuk terdiri dari bukan hanya masyarakat muslim namun terdapat pula agama-agama lain dan dengan berisikan berbagai macam bentuk karakter dan sifatny, maka menjadi sebuah jawaban bahwa tidak relevan jika sistem khilafah yang diusung oleh kelompok yang berfaham radikal hendak berusaha merubah sistem negaranya.

Sedangkan bagi komunitas pengusung ide khilafah memberikan penegasan bahwa, dimunculkannya kembali gagasan khilafah melalui media komunitas keagamaan siber disebut-sebut tidak hanya sekedar urusan politik, akan tetapi menjadi bagian dari dakwah Islam yang harus diperjuangkan. Pasalnya, khilafah adalah bagian dari ajaran Islam yang harus dilaksanakan, dan hukumnya adalah wajib bagi umat (Khilafah Channel, 2019b). Studi ini melihat bahwa narasi-narasi yang diunggah membuka respon terbuka sehingga terjadi perdebatan/diskursus khilafah dan ideologi kebangsaan yang ditampilkan melalui ruang room chat yang tersedia. Adapun perdebatan ini dalam prosesnya tidak selalu menunjukkan proses dialektika yang sehat dan diskursif. Akan tetapi, masih terlihat sebagian yang belum dapat menunjukkan harapan ideal tersebut. Dalam konteks ini, wajah agama (Islam) masih ditampilkan oleh komunitas keagamaan dalam bentuk perselisihan, perbedaan kepentingan ideologi mempengaruhi terhadap perselisihan itu.

Kehadiran agama seolah-olah tampil dalam media publik baru (media siber), belum sepenuhnya dapat memberikan gambaran sebagai agama yang ramah (Aguilera-Carnerero \& Azeez, 2016). Padahal, keberadaan agama sesungguhnya diperbolehkan ikut mewarnai ruang publik, meskipun tidak seluruh ruang publik bisa dimasuki oleh agama. Legalitas agama hanya ada pada wilayah yang bersifat rasional, seperti disebutkan John Rawls yaitu sebagai "public reason" (Horton, 2003). Sedangkan penghadiran agama dalam ruang publik baru ini dinilai sah-sah saja, dalam konteks lingkungan demokrasi. Sebab untuk dapat terwujud lingkungan yang demokratis, ruang publik harus membuka diri seluas-luasnya terhadap partisipasi keberagaman masyarakat (Hilmy, 2008).

Karena itu, munculnya wajah agama dalam ruang publik baru ini dinilai oleh Masdar Hilmy akan dapat menimbulkan kerentanan terhadap problem demokrasi yang sedang berlangsung secara terbuka bagi agama lain, pasalnya, simbol-simbol keagamaan yang diangkat ke permukaan sering "menohok" kelompok lain yang berasal dari agama berbeda (Hudjolly, 2011). Ekspresi keagamaan yang ditampilkan melalui dua media komunitas keagamaan siber menjadi lokus studi ini, sebab narasi-narasi yang saling berseberangan paham terhadap dua media komunitas ini bisa menjadi alasan menentukan lokus ini, hal ini dilakukan semata-mata agar dapat menjadi pintu masuk bagi peneliti sehingga dapat melakukan kajian lebih lanjut.

Masing-masing adalah media komunitas dakwah Islam Kaffah yang secara umum, pesan yang ditampilkan banyak menyampaikan gagasan tentang ide khilafah sebagai ajaran Islam. Berdasarkan penelusuran yang telah dilakukan, bahwa media komunitas dakwah Islam kaffah ini adalah bagian dari media siber yang dikembangkan oleh para pengusung ide khilafah Islamiyah di Indonesia. Hemat peneliti, gagasan tentang khilafah yang ditampilkan sepadan dengan misi ideologi salah satu organisasi sosial keagamaan yang telah dibekukan oleh pemerintah yaitu Hizbut Tahrir Indonesia (Kemala, 2017).

Asumsi ini didasarkan terhadap data hasil observasi terhadap narasi-narasi yang ditampilkan melalui media komunitas dakwah Islam kaffah, sebagian besar menyampaikan pesan-pesan tentang 
khilafah dan materinya disampaikan langsung oleh tokoh-tokoh eks HTI, seperti KH. Ismail Yusanto, KH Yasin Muthohar, Ustadz Yuana Ryan Tresna, M.Ag, KH. Rokhmat, S. Labib, dan lain-lainnya. Sementara, HTI sebelum dibekukan oleh pemerintah seringmengkampanyekan khilafahIslamiyah. Masdar Hilmy pernah menyebut bahwa doktrin khilafah Islamiyah diakui oleh para aktivis HTI sebagai antitesis ideologis yang siap menandingi, bahkan mengganti, posisi konsep negara-bangsa (NKRI) yang sudah dianggap final di Indonesia (Hilmy, 2014).

Sementara media komunitas siber lainnya adalah media komunitas siber yang dikembangkan oleh organisasi Nahdlatul Ulama (NU) seperti channel NU Online dan 164 Channel-Nahdlatul Ulama, berdasarkan analisis yang telah dilakukan dalam merespon isu khilafah, (Berdasarkan Penelusuran terhadap Kontens pada media siber NU Online) ini lebih cenderung membangun narasi penolakan (kontra) terhadap ide khilafah sebagaimana diekspresikan melalui media komunitas dakwah Islam kaffah. Pasalnya, ide khilafah tersebut dinilai bertentangan dengan ideologi kebangsaan yang telah diikat dalam Negara Kesatuan Republik Indonesia (NKRI) berdasarkan pancasila dan UUD 1945 serta Bhinneka Tunggal Ika.Melalui media komunitas siber, komunitas keagamaan ini dalam rangka melaksanakan dakwah Islam humanis dengan menekankan pada narasi keislaman sebagai agama yang moderat dan lebih damai. Moh. Fakhrurozi dalam karya bukunya menyebut masyarakat Islam dalam konteks global banyak menjadikan internet sebagai wahana dalam berdakwah (Fakhruroji, 2017).

Atas dasar inilah tulisan ini, diharapkan mampu memberikan gambaran tentang proses dialektika khilafah dan politik kebangsaan yang terjadi dalam ruang publik baru (media siber). Sehingga dapat dieksplorasi lebih jauh bagaimana ekspresi khilafah dan politik kebangsaan ditampilkan melalui dua media komunitas berbeda, selanjutnya bagaimana proses diskursus/perdebatan khilafah dan politik kebangsaan yang ditampilkan melalui media komunitas keagamaan siber ini dapat berlangsung, sebab jejak percakapan yang ditampilkan diwarnai juga oleh tampilan teks dan simbol-simbol lain yang menunjukkan adanya sentimen ideologi diantara komunitas keagamaan. Artikel ini dengan menggunakan perspektif ruang publik berupaya dapat memahami bagaiman proses dialektika berlangsung apakah menghasil konsensus, atau justru perdebatan ini terjadi berkepanjangan tanpa adanya konsensus.

Studi ini menggunakan analisis percakapan digital atau Digital Conversation Analysis sebagai metode dalam upaya memahami pesan-pesan keagamaan dan politik kebangsaan melalui teks, gambar, video dan simbol-simbol lainnya yang ditampilkan melalui ruang publik siber. Metode analisis percakapan bagian dari metode yang dikembangkan di tengah perkembangan lingkungan digital masyarakat serta munculnya berbagai jenis komunitas virtual, di mana komunikasi dan percakapan yang terjadi bersifat asynchronous. Berbeda dengan analisis percakapan tatap muka ( $C A$ tradisional) proses komunikasinya terjadi secara linier dalam urutan kronologis berjangka waktu, relatif singkat dengan tidak banyak orang yang terlibat dalam percakapan lisan. Analisis percakapan digital memungkinkan terjadinya diskusi online diikuti oleh banyak pengguna internet/pembaca melalui postingan komentar (respon) dan berlangsung secara tidak langsung (Asynchronous) (Giles, Stommel, Paulus, Lester, \& Reed, 2015; Virtanen \& Kääntä, 2018).

Analisis percakapan ini merupakan analisis yang menfokuskan perhatiannya pada interaksi dalam percakapan (Morissan, Andy Corry Wardhani, Farid Hamid U., 2013). Mengingat, realitas yang sedang dikaji lebih banyak diekspresikan melalui berbagai platform media sosial, maka harus menempatkan percakapan sebagai komponen utama teks media sosial yang dilakukan dalam penelitian ini. Bahasa dan struktur jejaring dalam interaksi yang diekspresikan oleh komunitas keagamaan. Karena itu, bahasa yang ditampilkan melalui narasi yang diunggah dalam bentuknarasi video ataupun teks serta percakapan yang menyertainya dapat menjadi petunjuk bagaimana ideologi khilafah dan politik kebangsaan ini sedang diperdebatkan oleh komunitas keagamaan.

Joanne Meredith (2017) dalam artikelnya tentang Analysing technological affordances of online interactions using conversation analysis, menyebutkan bahwa penggunaan analisis percakapan sebagai metode untuk menganalisis praktik interaksi komunikasi daring, meskipun telah berkembang dalam beberapa tahun terakhir, namun yang menjadi tantangan utama dalam menganalisis komunikasi daring 
adalah banyaknya platform tempat terjadinya interaksi, sedangkan yang harus dilakukan dalam menganalisis data-data ini tidak hanya mengandalkan pada proses interaksinya, tetapi juga pada konteks teknologi dari proses interaksi tersebut (Paulus, Warren, \& Lester, 2016).

Dengan demikian, secara faktual, teks tentang pesan keagamaan dan juga pesan menyangkut ide khilafah dan politik kebangsaan yang ditampilkan melalui media komunitas keagamaan siber dan diunggah dalam berbagai platform media sosial merupakan sebagai fenomena keagamaan yang tampil dalam bentuk percakapan secara online sehingga dapat digali prosesnya. Adapun percakapan ini berbeda dengan narasi-narasi yang dipublikasi melalui berbagai media komunitas online, sehingga teks tentang pesan keagamaan tampak sebagai sebuah wacana yang lebih interaktif. Atas dasar inilah studi ini bermaksud mengkaji dengan menggunakan perspektif "Ruang Publik" Habermas (2015), yang menekankan bahwa dalam proses dialektika diruang public harus terdapat consensus., sehingga dapat diketahui bagaimana dialektika ditampilkan oleh komunitas keagamaan melalui media publik siber.

Hasil studi yang pernah dilakukan oleh Garry R. Bunt (2003) memberikan pemahaman bahwa fenomena keagamaan dalam perkembangannya banyak dihadirkan dalam ruang-ruang digital/media internet, dalam hal ini, Bunt lebih menghadapkan pada realitas yang paradoks, yaitu antara ortodoksi Islam dengan realitas era digital yang heterodoks. Meskipun pada tingkatan tertentu, sesungguhnya lingkungan Islam maya dinilai sebagai tiruan. Pada konteks inilah studi ini menjadi penting dilakukan karena perbedaan pandangan dalam merespon ide khilafah dan politik kebangsaan pada tingkatan tertentu ternyata juga merepresentasikan terhadap fenomena keagamaan yang hadir dan dihadirkan melalui media komunitas keagamaan yang paradoks, apalagi wajah agama dalam konteks studi ini banyak diwarnai dengan perbedaan pendapat yang ditidak bisa dipisahkan oleh tekanan kepentingan ideologinya masing-masing.

\section{Ekspresi Khilafah dan Politik Kebangsaan dalam Media Publik Siber}

Tampilan pesan keagamaan yang diekspresikan melalui media komunitas keagamaan dalam, studi ini menunjukkan adanya narasi-narasi pemahaman khilafah dan politik kebangsaan dalam media siber, sebagai bagian dari fenomena kebebasan dengan memanfaatkan media siber sebagai ruang menampilkan paham ideologi dan keagamaannya, selain itu juga sebagai ruang dalam menyampaikan pendapat atau informasi kepada publik, seiring adanya perkembangan teknologi informasi dan komunikasi. Karena itulah kebebasan merespon ide khilafah ini merupakan bagian dari ciri masyarakat digital yang sedang ditunjukkan oleh komunitas keagamaan ditengah lingkungan demokrasi dewasa ini, yakni kebebasan dalam berekspresi (Dawson \& Cowan, 2004).

Realitas komunitas keagamaan dalam merespon khilafah dan ideologi kebangsaan ini diryang siber menunjukkan pengalaman dan situasi kebebasan yang sedang terjadi dilingkungan publik siber. Narasi tentang khilafah dan ideologi kebangsaan yang diekspresikan melalui media komunitas siber, berlangsung dengan tanpa ada tekanan dari pihak manapun. Meski demikian, dalam tatanan demokrasi yang deliberatif, maka kebebasan yang menjadikan bagian dari ciri demokrasi ini, seharusnya diimbangi dengan adanya sistem komunikasi yang lebih partisipatif. Dalam hal ini Wattimena menyebutnya sebagai agora elektronik yang dipahami sebagai ruang dalam cyberspace yang menjadi arena bagi seluruh warga masyarakat atau komunitas cyber untuk menyampaikan apapun aspirasi sosial-politik mereka (Sugihartati, 2014).

Berikut adalah sebagian ekspresi keagamaan dari dua media komunitas yang memiliki arah ideologi dan pemahaman berbeda khususnya dalam merespon ide khilafah dan politik kebangsaan tanah air Indonesia. Bahkan kedua media komunitas ini saling membangun narasi-narasi yang berseberangan pemahaman, masing-masing adalah sebagaimana hasil penelusuran yang telah dilakukan terhadap dua media komunitas yang ditetapkan sebagai lokus studi berikut ini. 
Media komunitas dakwah Islam kaffah merupakan media komunitas siber yang dimanfaatkan oleh komunitas pengusung ide khilafah untuk menampilkan gagasan tentang Negara khilafah Islamiyah. Melalui media komunitas ini, penjelasan dan penegasan tentang ide khilafah terus diperjuangkan, bahkan secara terang-terangan menampilkan tawaran alternative atas sistem demokrasi yang dinilai bukan bersumber dari ajaran Islam. Karena itu munculnya gagasan khilafah ini banyak mendapatkan respon kontra dari berbagai komunitas keagamaan lain, salah satunya seperti yang diekspresikan melalui media komunitas NU.

Urgensinya khilafah sehingga harus ditampilkan dalam media komunitas dakwah Islam kaffah ini adalah salah satunya karena dipahami sebagai kewajiban yang paling besar, yang diperintahkan oleh Allah SWT kepada hamba-hambanya, agar umat yang Islam bersatu diatas tali Allah SWT, bersatu dibawah naungan qur'an, mereka tidak bercerai berai, mereka tidak saling berselisih, tidak mungkin, umat manapun mereka akan selamat, dari bencana berpecah belah, perselisihan, kecuali jika umat itu menyerahkan, kepemimpinannya kepada orang besar diantara mereka yaitu imam, dalam hal ini kalimat ummat akan menyatu dibawah pendapat seorang imam, seorang pemimpin, dan perbedaan pendapat akan tunduk dibawah keputusan imam, sedangkan pemimpin ini merupakan bagian dari ummat. (Lihat dalam channel khilafah, Media komunitas dakwah Islam Kaffah, lihat (Khilafah Channel, 2019b).

Tentu, paham ideologi yang diekspresikan melalui media komunitas dakwah Islam kaffah ini banyak berseberangan dengan komunitas keagamaan lainnya. Data tentang narasi khilafah ini dapat dilihat pada saluran komunikasi yang digunakan oleh komunitas media dakwah Islam kaffah, yaitu melalui khilafah channel, focus khilafah channel, news khilafah, MMC dan lain-lain. Sementara untuk mendukung atas content dalam media ini, maka unggahan narasi ini juga sebarkan melalui platform media sosial lain yaitu youtube, facebook, instagram, twitterdan media sosial lainnya.

\section{Media Komunitas Nahdlatul Ulama; Khilafah Atau NKRI Harga Mati}

Ideologi khilafah yang dikembangkan di berbagai media sosial tidak sepenuhnya diterima oleh komunitas keagamaan. Dalam konteks ini, NU menjadi bagian dari komunitas yang kontra terhadap gagasan khilafah yang berkembangan di media siber. NU merespon ide atau gagasan tersebut dengan memberikan slogan tandingan yaitu dengan memuncullkan istilah "NKRI harga mati." Pilihan slogan ini dapat dilihat pada narasi-narasi yang diunggah melalui media komunitas NU. Studi ini memahami bahwa gagasan politik kebangsaan ini merupakan bagian dari ekspresi keagamaan yang ditampilkan oleh komunitas NU melalui media komunitasnya dan dilakukan dalam rangka merespon atas munculnya ide-ide khilafah yang dinilai berseberangan dengan sistem politik kebangsaan dalam Negara Kesatuan Republik Indonesia. (Data diperoleh dari jejak media komunita NU Online)

Sejumlah media digital berafiliasi dengan narasi-narasi yang dibangun oleh NU, sebagaimana paham yang ditampilkan melalui media komunitas NU menekankan bahwa khilafah merupakan bagian dari catatan sejarah pada satu sistem pemerintahan, dan dipahami sebagai fakta sejarah yang pernah dipraktikkan oleh al-Khulafa`al-Rasyidun. Dalam konteks ini NU menilai bahwa sistem pemerintahan pada masa itu, sangat mungkin dilakukan dengan menggunakan satu sistem khilafah. Akan tetapi, pada saat umat manusia bernaung di bawah negara-negara bangsa (nation states) maka sistem khilafah bagi umat sedunia, dinilai oleh NU adalah sistem pemerintahan yang sudah kehilangan relevansinya, selain itu, sistem khilafah ini juga dinilai utopia. Dalam hal ini Abdul Aziz melalui bukunya tentang kontroversi khilafah pernah menyebutkan bahwa khilafah ini sesungguhnya hanyalah sebagai nostalgia khilafah (Aziz, 2019).

Menghadapi paham khilafah sebagai ajaran Islam dan harus diterapkan sebagai sistem negara, NU mengambil sikap tegas yaitu dengan melakukan penolakan keras karena dinilai bertentangan dengan kesepakatan bersama. Hal ini bisa dilihat pada narasi-narasi yang ditampilkan melalui media komunitas NU dengan menunjukkan sikap dan pernyataannya bahwa Negara Kesatuan Republik Indonesia (NKRI) adalah harga mati. Sikap ini didasarkan pada sebuah pemahaman yang menunjukkan bahwa NKRI adalah hasil perjanjian luhur kebangsaan di antara anak bangsa pendiri 
negeri ini, dan NKRI dibentuk untuk mewadahi segenap elemen bangsa yang sangat majemuk dalam hal suku, bahasa, budaya dan agama. Media komunitas NU diperlukan sebagai saluran dengan menampilkan narasi-narasi kontra terhadap ide khilafah yang dipandang dapat membahayakan terhadap keutuhan bangsa Indonesia.

Kontra narasi terhadapa ide khilafah sebagaimana ditampilkan melalui saluran media komunitas NU, menjadi konten perlawanan terhadap ide khilafah yang dipahami sebagai propaganda yang telah dilakukan oleh pengusung khilafah. Kontra narasi yang banyak dimunculkan atau ditampilkan misalnya adalah narasi tentang paham kebangsaan yang didasarkan pada prinsip pancasila. Sebagaimana pernyataan Direktur NU Online, M. Syafic Ali saat wawancara dengan peneliti menyebutkan bahwa dalam rangka menandingi ide dan opini tentang ekstrimisme keagamaan seperti ide khilafah, maka perlu dilakukan perluasan penyebaran konten keagamaan sebagaimana pahamnya NU, sehingga ruang publik tidak didominasi oleh narasi-narasi keagamaan dari komunitas pengusung ide Khilafah (M. Syafic Ali, Komunikasi Personal, 6 Juli 2019).

Berdasarkan penjelasan yang disampaikan Syafic Ali, maka akan terlihat sangat wajar bila media digital NU terus melakukan upaya penguatan dan perluasan saluran komunikasi, sehingga saluran itu dapat berfungsi sebagai ruang bagi NU dalam melaksanaan kewajibannya melakukan dakwah Islam dan amar makruf nahi munkar. Pasalnya pada era digital ini, setiap orang dengan mudah dan sangat cepat dalam mencari sumber-sumber informasi dalam kehidupan keagamaan, maka tingkat kehati-hatian dalam mencari sumber informasi keagamaan ini menentukan terhadap persepsi dan pemahaman keagamaan.

Dengan demikian, mempertimbangkan narasi-narasi yang ditampilkan oleh dua media komunitas keagamaan yaitu media komunitas dakwah Islam kaffah yang lebih banyak menampilkan pemahaman bahwa khilafah sebagai ajaran Islam dan wajib dijalankan oleh umat muslim, serta tampilan penolakan atas pemahaman khilafah tersebut seperti yang ditampilkan melalui media komunitas NU, maka studi ini memahami bahwa perbedaan pandangan dan pemahaman keagamaan tersebut merupakan bagian dari ekspresi keagamaan seiring dengan lahirnya ruang public baru, inilah realitas keagamaan yang sedang ditampilkan melalui media komunitas keagamaan, meskipun masing-masing media komunitas memiliki corak pemahaman yang saling berseberangan.

\section{Diskursus Khilafah dan Politik Kebangsaan dalam Ruang Siber}

Dalam filsafat dialektika Hegel (2012), disebutkan bahwa segala sesuatu adalah sintesis dialektis dari momen sebelumnya, dan kebebasan yang telah actual atau konkret, dalam sebuah Negara juga tidak akan tercapai dengan sendirinya, tetapi sebagai sintesis dialektis dari momen-momen sebelumnya (Hardiman, 2010). Dari sinilah perlu melihat fenomena keagamaan yang ditandai dengan adanya diskursus/perdebatan khilafah dan politik kebangsaan diantara komunitas keagamaan melalui media komunitas, sedang berlangsung dalam ruang publik siber, sehingga dapat diketahui bagaimana posisi masing-masing media komunitas terlibat dalam perdebatan/ diskursus tentang khilafah dan politik kebangsaan ini.

Beberapa isu menjadi fokus dalam diskursus ini, antara lain: tentang faham khilafah yang dipahami sebagai ajaran Islam atau dipahami sebagai sebuah fakta sejarah. Dalam hal ini khilafah dipahami sebagai bagian dari ajaran agama Islam dan hukumnya adalah fardlu, yang diwajibkan kepada umat Islam untuk dilaksanakan, bahkan kewajiban ini bersifat muhtam, bahkan dalam sebuah referensi disebutkan bahwa khilafah ini merupakan sebagai institusi yang bertanggung jawab dalam menerapkan hukum-hukum syariat dan mendakwahkannya kepada umat manusia adalah suatu keharusan (Faiz, 2003).

Berdasarkan data yang telah ditelusuri menyebutkan bahwa khilafah dipahami sebagai jabatan keagamaan, hal ini disebutkan oleh Yasin Muthohar bahwa kedudukan jabatan ini bersifat agama, karena setelah nabi SAW tidak ada lagi dimuka bumi ini, dan yang meneruskan fungsi kenabian yaitu harus adanya kepemimpinan kekhalifahan bagi kaum muslimin. Karena itulah, khilafah ini memiliki urgensitas dan menjadi kewajiban yang paling besar bagi kaum muslimin, sebagaimana yang diperintahkan oleh Allah SWT kepada hamba-hamba-Nya, sehingga umat muslim dapat 
bersatu diatas tali Allah SWT, dan juga dapat bersatu dibawah naungan al-Quran al-Karim (Khilafah Channel, 2020a).

.....Khilafah Islamiyah adalah penjaga negeri kaum muslimin, penjaga darah kaum muslimin, tanpa khilafah maka kita melihat darah-darah kaum muslimin ditumpahkan begitu mudah, begitu murah, kaum muslimin dimana-mana ditindas, Dan hari ini kita tidak memiliki imam yang menjaga darah, menjaga negeri, menjaga harta bagi kaum muslimin, sehingga wajar kalo hari ini, harta-harta yang ada dinegeri kaum muslimin, lepas ketangan musuh, karena penguasapenguasa hari ini bukanlah penguasa yang menerapkan hukum Allah, mereka bukanlah penguasa keturunan tertinggi dari kaum muslimin, yaitu kholifah... (Khilafah Channel, 2019a)

Dalam media komunitas yang sama, M. Shiddiq Al-Jawi, menyebut bahwa khilafah memiliki kesamaan dengan imamah (sinonim), beberapa sumber dianggap memiliki dasar yang kuat dalam pemahaman ini, seperti pendapat yang didasarkan terhadap pandangannya Imam Mawardi, bahwa imamah (khilafah) itu ditetapkan sebagai pengganti kenabian dalam pemeliharaan agama, dan pengaturan urusan dunia dengan agama. Selain itu juga didasarkan terhadap pandangan Imam al Haramain yang menyebutkan bahwa khilafah merupakan suatu kepemimpinan menyeluruh dan suatu pengaturan yang terkait dengan urusan khusus dan umum dalam kepentingan agama dan dunia (Khilafah Channel, 2020b).

Berikut adalah gambaran tentang jejak percakapan yang mengarah pada kesepahaman komunitas dengan narasi-narasi yang diunggah melalui media komunitas dakwah Islam Kaffah sebagaimana dalam tabel 1 (data teks percakapan ini diunggah dalam media komunitas siber, khilafah channel).

Tabel 1 Sebagian Jejak Percakapan Merespon Positif terhadap Narasi Khilafah

\begin{tabular}{l|l}
\hline Identitas & Isi Komentar \\
\hline Aulia Fakhrunnisa' & $\begin{array}{l}\text { We need khilafah sbg solusi persoalan ummah } \\
\text { dwis nibiu }\end{array}$ \\
Novi Allah ya Rabb... & $\begin{array}{l}\text { Semoga kita senantiasa diberikan petunjuk dalam memperjuangkan Khilafah } \\
\text { Fahrul Anwar }\end{array}$ \\
Maulana Yusuf & $\begin{array}{l}\text { Khilafah solusi bagi seluruh problematika kehidupan manusia } \\
\text { Adi Sitohang }\end{array}$
\end{tabular}

Sementara itu, munculnya kembali ide khilafah dalam ruang publik siber ini mendapatkan respon balik berupa penolakan dan counter narasi yang disampaikan oleh banyak komunitas keagamaan lain, terutama respon yang berasal dari organisasi sosial keagamaan mainstraim seperti NU dan Muhammadiah, misalnya saja penolakan NU yang terekspresikan melalui media komunitas siber Nahdlatul Ulama. Menunjukkan bahwa narasi penolakan dilakukan karena pemahaman khilafah dinilai telah menyalahi prinsip politik kebangsaan yang telah disepakati oleh umat Islam sebelumnya, yaitu sistem pemerintahan yang dibingkai dalam Negara Kesatuan Republik Indonesia (NKRI).

Berdasarkan data yang telah ditelusuri dari media komunitas NU disebutkan bahwa khilafah adalah bagian dari fakta sejarah yang pernah terjadi dalam Islam, yaitu sistem khilafah pernah dipraktikkan oleh al-Khulafa al-Rasyidin, artinya sistem pemerintahan pada masa itu, sangat dimungkinkan untuk dilaksanakan, sementara, seiring dengan dinamika dan perkembangannya pada saat umat manusia telah bernaung di bawah negara-negara bangsa (nation states), maka sistem khilafah sebagai sistem pemerintahan bagi umat sedunia saat ini sudah kehilangan relevansinya, bahkan sistem khilafah ini juga dipahami sebagai sistem yang dianggap utopis (NU Online, 2018).

Dalam media komunitas yang dikelola oleh NU, Said Aqil Siroj menyebutkan bahwa sistem khilafah Islam telah dinyatakan bubar, sejak runtuhnya sistem khilafah usmani di Turki pada tahun 1924 yang silam, bahkan hingga perkembangan keagamaan dan kebangsaan di Indonesia seiring 
dengan kemerdekaan NKRI juga dipengaruhi oleh dinamika khilafah yang terjadi dinegara-negara Arab. Karena itu umat muslim diharapkan bisa memahami bagaimana dinamika yang pernah terjadi pada masa-masa bubarnya sistem khilafah itu pernah terjadi. (NU Channel, 2019),

.....Khadrotus Syaikh KH Hasyim Asyari sudah mengetahui bahwa khilafah akan segera bubar, maka, sebelum system khilafah bubar, beliau KH Hasyim telah memiliki gagasan tentang nasionalisme yang religious, agar bangsa ini tidak berkembang menjadi negara yang nasionalis tetapi sekuler, maka dikeluarkanlah jargon yang sangat terkenal yaitu "Khubbul Wathan Minal Iman". Artinya, Nasionalisme adalah bagian dari iman.." (NU Channel, 2019).

Sedangkan, Cholil Nafis menyebutkan persoalan khilafah Islamiyah adalah persoalan ijtihadi yang masih membuka khilafiyah atau masih membuka ruang perbedaan. Karenanya HTI dianggap telah gagal paham dalam bidang agama yang sudah mengharamkan sesuatu yang halal (berbedabeda pendapat) dengan menyebut khilafah Islamiyah sebagai persoalan yang pasti (qot'i) (Sofiuddin, 2017).

Narasi tersebut menimbulkan reaksi yang cukup beragam, sebagian diantara komentar publik tersebut harus merespon positif dan mengelu-elukan atas narasi yang diunggah, namun sebagian lagi juga merespon negatif dengan membuat tulisan kontra pada dinding percakapan dimasing-masing ruang media komunitas siber,seperti terlihat dalam percakapan publik yang ditampilkan dalam merespon penjelasan khilafah yang diunggah dalam media komunitas dakwah Islam kaffah. (Khilafah Channel, 2020b).

Berikut adalah gambaran tentang jejak percakapan yang mengarah pada kesepahaman komunitas dengan narasi-narasi yang diunggah melalui media komunitas NU, sebagaimana dalam tabel 2 (data teks percakapan ini diunggah dalam media komunitas siber NU).

Tabel 2 Sebagian Jejak Percakapan Merespon Positif terhadap Narasi Penolakan Khilafah

\begin{tabular}{|c|c|}
\hline Nama Netizen & Isi Komentar \\
\hline Ahmad Hadi & Bersatulah bangsaku, dalam bingkai NKRI, Berdasar Pancasila dan UUD 45 \\
\hline Zaenal Abidin & $\begin{array}{l}\text { Udah2. yg gk setuju dengan PANCASILA dan UUD silahkan Keluar dari } \\
\text { INDONESIA. }\end{array}$ \\
\hline Ali Maksum & $\begin{array}{l}\text { semua sok pinter, baru baca sekali kaya yg udh mengalami dan menghukumi yg lain, } \\
\text { sekarang aja laksanakan kebaikan sesama dan jngan melangggar tatanan }\end{array}$ \\
\hline RAJET & bersatulah wahai umat Islam karena hanya Allah tujuan kita \\
\hline Mukadas & Wes Gak usah neko" bila bangsa Indonesia mau mengamalkan pansilala dari sila satu \\
\hline Spdsd & $\begin{array}{l}\text { sampai sila lima saya yakin pasti Allah akan menjadikan bangsa kita bangsa yg hebat } \\
\text { dimuka bumi ini }\end{array}$ \\
\hline Abdul Junaidi & $\begin{array}{l}\text { Khilafah itu Bukan milik } 1 \text { negara,1 amir nya, memimpin seluruh dunia, jadi tiap } 2 \\
\text { negara2 didunia akan jadi provinsinya...waduhh...kebayang gk beratnya terbentuknya } \\
\text { khilafah? wallahualam }\end{array}$ \\
\hline SUARA NU & $\begin{array}{l}\text { @ Abdul Junaidi nggak akan mungkin terwujud, kecuali ada superpower yg punya } \\
\text { senjata untuk menaklukkan dunia, wallahu alam }\end{array}$ \\
\hline
\end{tabular}

Berdasarkan analisis percakapan tentang ide khilafah dan politik kebangsaan ini, respon Prokontra juga mewarnai dalam proses perdebatan yang ditampilkan dalam kolom komentar pada dinding kolom komentar pada masing-masing media komunitas siber. Misalkan percakapan publik yang ditampilkan dalam kolom komentar merespon video dokumentasi pidato KH Said Aqil Siraj tentang ma'rifat kyai Hasyim Asyari bahwa khilafah akan bubar, serta video dokumentasi yang lainnya, secara umum respon tersebut memberikan unkapan respon positif namun sebagian yang lain juga menulis komentar kontra pada dinding kolom komentar (TVNU Televisi Nahdlatul Ulama, 2020).

Perdebatan terkait pilihan ideal dalam membangun bangsa antara sebagai negara khilafah atau NKRI, juga mewarnai terhadap perdebatan antar komunitas keagamaan yang berlangsung secara 
terbuka dalam ruang publik siber ini, satu sisi ide khilafah disebut-sebut sebagai gagasan yang dapat mengancam keutuhan NKRI dan Pancasila, tetapi di sisi yang lain komunitas pengusung ide khilafah sendiri tidak mengakuinya sebagai komunitas yang menentang terhadap NKRI. Namun demikian, kampanye tentang khilafah secara massif terus dilakukan melalui media komunitas siber, bahkan sejumlah kontens diunggah dalam media komunitas dakwah Islam kaffah, dan cenderung banyak menampilkan penjelasan tentang idealnya negara khilafah seperti yang dicita-citakan dalam upaya menegakkan syariat Islam secara Kaffah.

Narasi-narasi ini memicu terjadinya perdebatan panjang yang tampil secara terbuka dan bebas melalui percakapan antar komunitas keagamaan yang berlangsung secara berjejaring. Bahkan melalui media komunitas siber, mereka saling bersaing dan memperebutkan pengaruh public. Dalam hal ini, satu sisi media komunitas dakwah Islam kaffah banyak menampilkan narasi tentang khilafah, sedangkan disisi yang lain melalui media komunitas organisasi Nahdlatul Ulama (NU) menampilkan counter narasi atas ide khilafah yang dinilai bertentangan dengan arah politik kebangsaan dalam bingkai Negara Kesatuan Republik Indonesia (NKRI).

Realitas dialektika yang terjadi dalam ruang publik siber ini menunjukkan adanya realitas kebebasan bagi komunitas keagamaan dalam mengekspresikan paham ideologinya, seiring dengan perkembangan teknologi informasi dan komunikasi, termasuk dalam menyampaikan pendapat atau informasi kepada publik luas. Dan kebebasan yang telah diekspresikan dalam merespon ide khilafah melalui media komunitas siber ini adalah bagian dari ciri masyarakat digital yang sedang ditunjukkan oleh komunitas keagamaan ditengah lingkungan demokrasi dewasa ini (Dawson \& Cowan, 2004).

Berdasarkan filsafat dialektika Hegel, sebagaimana prinsip penting filsafat Hegel menyebutkan bahwa segala sesuatu adalah sintesis dialektis dari momen sebelumnya, dan kebebasan yang telah actual atau konkret dalam sebuah Negara juga tidak tercapai dengan sendirinya, tetapi sebagai sintesis dialektis dari momen-momen sebelumnya (Hardiman, 2010), maka diskursus/perdebatan khilafah dan politik kebangsaan ini sesungguhnya menunjukkan adanya pertarungan antara komunitas keagamaan yang ditampilkan melalui media komunitas siber, mereka berada dalam posisi yang saling berlawanan.

Sementara, dialektika secara konseptual dipahami sebagai dua hal yang dipertentangkan lalu didamaikan, atau biasa dikenal dengan tesis (pengiyaan), antitesis (pengingkaran) dan sintesis (kesatuan kontradiksi). Artinya, pengiyaan dalam hal ini harus berupa konsep pengertian yang empiris indrawi, dan pengertian yang terkandung di dalamnya berasal dari kata-kata sehari-hari, spontan, bukan reflektif sehingga terkesan abstrak, umum, statis dan konseptual. Sedangkan pengingkaran merupakan konsep pengertian pertama (pengiyaan) yang dilawan-artikan, sehingga muncul konsep pengertian kedua yang kosong, formal, tak tentu dan tak terbatas, artinya kontradiksi merupakan sebagai motor dialektika yang harus mampu membuat konsep bertahan dan saling mengevaluasi (Aiken \& Djatmiko, 2009).

Jika mencermati perdebatan khilafah sehingga menimbulkan perdebatan diantara komunitas keagamaan yang terjadi dalam ruang publik siber ini jelas menunjukkan adanya sikap pengiyaan (pro-tesis) atas tesis terhadap sistem demokrasi yang dilandaskan pada UUD 1945, Pancasila, Bhinneka Tunggal Ika dan NKRI. Sedangkan ide khilafah yang diekspresikan melalui media komunitas dakwah Islam kaffah adalah anti tesis atau dapat disebut sebagai wujud pengingkaran terhadap tesis tentang system demokrasi pancasila yang telah menjadi sistem politik kebangsaan. Pengingkaran terhadap tesis ini salah satunya didasarkan pada ekspresi yang ditampilkan melalui media komunitas dakwah Islam kaffah, yang banyak menyebutkan penolakannya terhadap system demokrasi Indonesia yang dinilai bukan dilahirkan oleh Islam. Seperti ditegaskan oleh Yusanto bahwa paham demokrasi memberikan pemegang kedaulatan sepenuhnya dalam membuat hukum kepada rakyat atau wakil rakyat adalah paham yang dinilai bertentangan dengan ajaran Islam. Sebab dalam ajaran Islam kedaulatan atau hak untuk membuat hukum hanya berada ditangan Allah, bukan ditangan rakyat atau wakil rakyat sebagaimana paham dalam demokrasi (Yusanto, 2016). 
Selain itu narasi-narasi yang mengandung ajakan dan penegasan atas penerapan syariat Islam melalui system khilafah banyak diekspresi melalui media komunitas dakwah Islam kaffah. Berdasarkan data yang telah ditelusuri menunjukkan bahwa media komunitas dakwah Islam kaffah banyak menampilkan video narasi yang membahas tentang tawaran ideologi Islam sebagai solusi alternatif. Sistem politik kebangsaan yang selama ini telah dijalankan oleh pemerintah, dinilai tidak memberikan ruang gerak yang bebas bagi masyarakat muslim dalam menjalankan syariat Islam secara kaffah. Bahkan dengan sistem yang ada juga tidak mampu menyelesaikan persoalan-persoalan yang sedang dihadapi oleh bangsa. Pasalnya, pemerintahan rezim yang sedang berkuasa tidak bisa melepaskan diri dari cengkeraman dominasi ideologi sekuler yang berpangkal melalui sistem demokrasinya.

Problem yang sedang dihadapi bangsa ini, dinilai berpangkal pada sistem yang terlahir dari pandangan hidup yang dinilai salah, yaitu sekularisme. Solusi fundamental yang paling tepat untuk ditawarkan kepada public adalah dengan cara menghentikan sistem sekuler itu dan menerapkan kembali seluruh tatanan yang berlandaskan pada syariat Islam (Yusanto, 2016). Karena itulah melalui saluran media komunitas dakwah Islam kaffah terus menyampaikan kampanye dan ajakannya kepada umat muslim Indonesia agar dapat menerima dan ikut memperjuangkan penerapan syariat Islam melalui sistem khilafah.

Pemahaman khilafah yang diekspresikan dalam media komunitas dakwah Islam kaffah ini memperkuat hipotesis tentang gerakan Islam dalam konteks global, seperti yang pernah dilakukan oleh Bassam Tibbi melalui karya bukunya tentang Islamisme and Islam. Tibi melakukan identifikasi komunitas pengusung ide khilafah sebagai bagian dari gagasan keagamaan yang sering dimanfaatkan oleh kelompok tertentu dalam mempromosikan suatu tatanan politik yang dipercaya beremanasi dari kehendak Allahdan bukan berdasarkan terhadap kedaulatan rakyat.Tibbi menyebut sebagai bagian dari fenomena fundamen-talisme agama yang dikatagorisasi sebagai bagian dari Islamisme (Tibi, 2016).

Sementara, dalam konteks Indonesia, pemahaman khilafah yang diekspresikan melalui media komunitas dakwah Islam kaffah ini merepresentasi terhadap pemahaman khilafah yang pernah dikampanyekan oleh Hisbut Tahrir Indonesia (HTI) sebelum dibekukan ijin organisasinya oleh pemerintah pada tahun 2017 silam. Hal ini dapat dilihat pada setiap kontens pemahaman khilafah yang ditampilkan melalui media komunitas dakwah Islam kaffah, selain memiliki ajaran yang serupa, kontens dalam narasi yang diunggah pada media komunitas dakwah Islam kaffah ini disampaikan oleh narasumber-narasumber yang dulunya adalah tokoh dan fungsionaris HTI. Yaitu bagian dari organisasi yang dulunya dikategorisasi sebagai komunitas keagamaan yang ekstrimis/radikal (meskipun identifikasi ini juga ditolak oleh HTI).

Masdar Hilmy dalam karyanyatentang Radikalisme Agama Dan Politik Demokrasidi Indonesia PascaOrde, menyebutkan bahwa organisasi HTI adalah bagian dari komunitas keagamaan yang termasuk dalam kelompok radikalismeIslam, HTI dan beberapa komunitas keagamaan radikalis lainnya muncul akibat dampak dari semakin terbukanya iklim politik dan demokrasi pasca tumbangnya Orde baru (Hilmy, 2015). Bahkan, dalam karyanya yang lain Hilmy (2014) menyebutkan bahwa HTI adalah bagian dari komunitas Trans-Nasional. Hal serupa juga diungkapkan oleh Syamsul Arifin dalam karyanya tentang utopia negaara khilafah; Ideologi dan gerakan sosial Hizbut Tahrir bahwa setelah diadakan penelitian baik secara hermeneutic terhadap sejumlah dokumen Hizbut Tahrir maupun melalui penelitian empiric, sehingga dapat disimpulkan bahwa Hizbut Tahrir bisa dikelompokan sebagai gerakan keagamaan yang memiliki orientasi ideologi fundamentalistik (Arifin, 2018).

Menanggapi tentang organisasi HTI ini, Azyumardi Azra, saat hadir sebagai saksi ahli dalam sidang lanjutan gugatan HTI terkait dengan pembubaran organisasi tersebut, menyatakan bahwa konsep khilafah yang diusung oleh HTI sangat berbahaya bagi eksistensi Pancasila dan Negara Kesatuan Republik Indonesia (NKRI), dan pembubaran HTI disebutkan sebagai reaksi pemerintah terhadap ancaman dari organisasi yang menginginkan ajaran Islam diterapkan di Indonesia.Dikutip sejumlah penelitian menemukan bahwa konsep khilafah HTI sebagai entitas politik untuk 
menggantikan NKRI, Pancasila, dan UUD 1945 adalah bukanlah berorientasi pada ajaran agama, dan gerakan khilafah ini berbahaya bagi kelanjutan NKRI. Disebutkan Azyumardi Azra, pada saat Pengadilan Tata Usaha Negara (PTUN), 2018, bahwa pemerintah Jokowi yang telah mengambil langkah drastis dalam menghadapi HTI, meskipun pemerintah tidak secara langsung membuat aturan pembubaran HTI, dan pemerintah membuat aturan pembubaran ormasy yang dianggap bertindak tak sesuai Pancasila dan UUD 1945. Peluang terbentuknya negara Islam di Indonesia dinilai oleh Azyumardi adalah sangat tidak mungkin untuk diwujudkan, pasalnya, mayoritas umat Islam di Indonesia adalah muslim yang telah berkomitmen kepada NKRI dan Pancasila. Apalagi ormas mainstream diindonesia seperti Nahdlatul Ulama dan Muhammadiyah telah menyatakan mendukung terhadap NKRI (Florentin, 2018).

Tabel 3 adalah sebagian kecil, gambaran bagaimana teks yang ditampilkan melalui media komunitas keagamaan siber, menunjukkan terjadinya benturan Narasi Khilafah dan Politik Kebangsaan diantara komunitas keagamaan.

Tabel 3 Benturan Narasi Khilafah (diambil dari jejak narasi dan percakapan yang terekam melalui media komunitas siber)

\begin{tabular}{|c|c|c|}
\hline No & Narasi Pro Khilafah & Narasi Kontra Khilafah \\
\hline 1. & $\begin{array}{l}\text { Khilafah adalah jabatan keagamaan, } \\
\text { kedudukan yang bersifat agama, setelah } \\
\text { nabi SAW tidak ada lagi dimuka bumi } \\
\text { ini, dan yang meneruskan fungsi } \\
\text { kenabian yaitu harus adanya } \\
\text { kepemimpinan kekhalifahan bagi kaum } \\
\text { muslimin. }\end{array}$ & $\begin{array}{l}\text { Paham khilafah ala HTI bertentangan dengan } \\
\text { sistem politik kebangsaan yang telah diikat } \\
\text { dalam sistem NKRI, berdasarkan Pancasila } \\
\text { UUD } 1945 \text { dan Bhinneka tunggal Ika }\end{array}$ \\
\hline 2. & $\begin{array}{l}\text { Khilafah adalah ajaran agama Islam, dan } \\
\text { hukumnya menjalankan bagi umat } \\
\text { muslim adalah fardlu, bahkan kewajiban } \\
\text { ini bersifat muhtam }\end{array}$ & $\begin{array}{l}\text { Khilafah adalah fakta sejarah dalam Islam, } \\
\text { paham khilafah bersifat ijtihadi, yang sangat } \\
\text { mungkin menjadi perdebatan sebagai ajaran } \\
\text { Islam }\end{array}$ \\
\hline 3. & $\begin{array}{l}\text { Dengan Khilafah umat muslim dapat } \\
\text { bersatu diatas tali Allah SWT, dan juga } \\
\text { dapat bersatu dibawah naungan al-Quran } \\
\text { al-Karim }\end{array}$ & $\begin{array}{l}\text { Sejengkalpun tanah di negeri ini tidak akan } \\
\text { pernah dibiarkan untuk dapat dikuasai oleh } \\
\text { para pengusung khilafah }\end{array}$ \\
\hline 4. & $\begin{array}{l}\text { Khilafah solusi bagi seluruh problematika } \\
\text { kehidupan manusia }\end{array}$ & $\begin{array}{l}\text { Sistem khilafah Islam telah dinyatakan bubar, } \\
\text { sejak runtuhnya sistem khilafah ustmani di } \\
\text { turki pada tahun } 1924 \text { silam }\end{array}$ \\
\hline 5. & Khilafah Solusi Tuntas Problemtika Umat & $\begin{array}{l}\text { sistem ideologi kebangsaan Indonesia adalah } \\
\text { bagian dari hasil dari perjanjian luhur } \\
\text { kebangsaan yang telah dilakukan oleh para } \\
\text { anak bangsa. }\end{array}$ \\
\hline
\end{tabular}

\section{Penalaran Publik Siber Menuju Deliberative}

Dipahami bahwa media Siber berfungsi sebagai public sphere, ruang diskursif, dan sebagai saluran bertemunya wacana sehingga tercipta interaksi antar komunitas, berdasarkan konsep ruang publik Habermas, disebutkan sebagai wilayah kehidupan sosial dimana opini publik dapat terbentuk (Hardiman, 2010).

Kehadiran media komunitas dakwah Islam kaffah dan media komunitas siber NU, selain menjadi sarana untuk meneguhkan pemahaman ideologi komunitas keagamaannya, juga sebagai sarana mempengaruhi persepsi public agar dapat menjadi bagian dari komunitasnya. Karena itu munculnya kembali ide Khilafahmelalui media komunitas dakwah Islam kaffah, selain sebagai 
peneguhanatas ide khilafah, Tampilan ekspresi ini juga dapat menjadi pemantik terhadap perdebatan/diskursus diantara komunitas keagamaan.

Dalam pandangan Jurgen Habermas ditekankan bahwa Ruang Publik setidaknya dapat menjadi ruang mediasi yang memungkinkan terjadinya pertukaran ide yang demokratik yang ditandai oleh terjadinya debat terbuka, alternatif, kepercayaan dan mutual (Hardiman, 2010). Sehingga ruang publik siber ini dimungkinkan bisa mewujudkan demokrasi yang deliberative. Disebutkan oleh Habermas juga bahwa untuk mewujudkan demokrasi deliberative, diperlukan beberapa syarat, salah satunya adalah adanya komunikasi intensif antara sistem politik dengan ruang publik (Priyono, Samadhi, \& Tornquist, 2005).

Karena itu, berdasarkan data yang diperoleh dari percakapan dan narasi sebagaimana jejak digital yang telah ditelusuri menunjukkan bahwa dalam proses dialektika nampak adanya persoalan kebebasan bagi masing-masing komunitas keagamaan. Sebab, kebebasan ini selain diwarnai sebagai ruang diskursus antar komunitas, dalam praktiknya juga diwarnai oleh tampilan narasi dan percakapan yang cenderung masih menampakkan adanya sentiment ideologi diantarakomunitas keagamaan.

Berdasarkan analisis yang telah dilakukan oleh peneliti menunjukkan bahwa adanya kompetensi komunikatif sesungguhnya menjadisignifikan dalam proses dialektika yang sesungguhnya harus ditampilkan secara bebas dari tekanan pihak manapun. Artinya proses komunikasi dapat diperoleh dari proses yang genuine. Yaitu, komunikasi yang tidak terdistorsi secara ideologis, dan keberhasilannya akan memberikan hasil komunikasi yang genuinesehingga dapat terbebaskan dari distorsi ideologis.

Perdebatan tentang munculnya ide khilafah antara komunitas dakwah Islam kaffah dengan komunitas siber NU tidak hanya ditampilkan dalam bentuk narasi saja, tetapi juga terekspresikan dalam percakapan pada kolom komentar pada masing-masing platform media komunitas siber. Dalam hal ini, publik digital menjadi bagian dari aktor-aktor publik, memiliki kebebasan dalam berekspresi, berpikir, berbicara dan bahkan juga dapat berkomunikasi tanpa diskriminasidan represi dari pihak manapun. Meskipun perdebatan ini juga sesungguhnya dapat menimbulkan reaksi publik sehingga terjadi benturan diantara komunitas keagamaan yang lainnya. Studi ini memahami bahwa perdebatan tentang ide khilafah yang ditampilkan melalui ruang publik siber ini adalah bagian dari wujud penghadiran agama yang diekspresikan melalui perdebatan dalam ruang-ruang publik siber.

Tentang penghadiran agama pada ruang publik ini, sebelumnya pernah diingatkan oleh John Rawls melalui "Rasionalitas public", menurutnya bahwa agama boleh mewarnai ruang public, tetapi tidak seluruh ruang public bisa dimasuki oleh agama, sebab legalitas agama hanya ada pada wilayah yang bersifat rasional (Hilmy, 2008). Seperti pernah digambarkan oleh Hudjolly, bahwa agama untuk memasuki ruang publik setidaknya harus memenuhi beberapa syarat, yaitu menggunakan penyembunyian (monstrasi) dan menampakkan (demonstrasi) objek keagamaan (Hudjolly, 2011).

Dalam hal ini, nilai yang dimonstrasi adalah nilai yang kerap disebut sebagai nilai yang sakral, terma khusus agama yang berbasis teks dan bersifat fundamental. Sedangkan, nilai yang ditampakkan adalah wajah agama yang serba-humanis, plural, dengan begitu humanisme dan pluralisme menjadi sarana tampilan saja demi bisa diterimanya agama berada dalam ruang publik (Hilmy, 2014). Karena itulah Masdar Hilmy pernah memberikan penegasan bahwa penghadiran agama dalam ruang public sesungguhnya dinilai sah-sah saja, apalagi dalam konteks demokrasi, ruang public harus membuka diri seluas-luasnya terhadap partisipasi keberagaman bagi masyarakat luas (Hilmy, 2008).

Sementara munculnya kembali wajah agama melalui media komunitas agama siber dalam ruang publikselain sebagai ruang peneguhan terhadap demokrasi, juga bisa membuka ruang baru dan menimbulkan kerentanan terhadap problem demokrasi itu sendiri. Hal ini disebut oleh Hilmy karena dalam ruang public banyak ditemukan simbol-simbol keagamaan yang diangkat dalam ke permukaan ruang publik, namun kecenderungannya symbol keagamaan tersebut sering "menohok" terhadap kelompok lain (Hilmy, 2014). 
Artinya ketika perdebatan ide khilafah yang diekspresikan melalui ruang publik siber ini ditampilkan dengan menggunakan symbol-symbol keagamaan baik dalam bentuk tulisan, gambar, atau narasi-narasi yang dapat menimbulkan reaksi keras bagi kelompok yang lain, maka keberadaan ruang publik siber ini sesungguhnya juga dapat menjadi kerentanan tersendiri bagi demokrasi.Karenanya perdebatan pandangan tentang ide khilafah ini semestinya dapat menampilkan perdebatan yang tidak menimbulkan ekses-ekses destruktif, seperti rusaknya tatanan kehidupan public ataupun munculnya ketakutan-ketakutan dari kelompok yang lainnya.

Memperhatikan kontradiksi yang ditampilkan dalam ruang publik siber ini, maka kontradiksi ini semestinya ditempatkan sebagai motor dialektika yang harus mampu membuat konsep bertahan dan saling mengevaluasi diantaranya. Sehingga yang terjadi perdebatan diantara komunitas keagamaan yang saling berlawanan (pro-kontra), akan melahirkan/tercipta sebuah konsep baru tentang pandangan politik kebangsaan yang lebih ideal. Diingatkan oleh Habermas (2015) sebelumnya bahwa untuk mewujudkan konsep baru yang lebih ideal ini, proses dialektika harus didasarkan pada tindakan komunikasi bagi masing-masing kelompok keagamaan yang saling berkontradiksi.

Atas dasar inilah, maka dalam pembahasan ini, perlu diuraikan beberapa hal yang berkaitan dengan upaya penalaran public dalam diskursus khilafah dan politik kebangsaan yang saling kontradiksi pandangan sebagaimana ekspresi ideology komunitas keagamaan yang telah ditampilkan dalam media komunitas dakwah Islam kaffah dan media komunitas NU. Masingmasing adalah sebagaimana berikut ini:

Pertama, Penalaran public dalam upaya membuka ruang consensus dalam proses dialektika ini, dapat dipahami dengan memberikan penegasan pada subtansi persoalan pada masing-masing isu yang sedang diperdebatkan, yaitu perbedaan pandangan dan pemahaman dalam memaknai khilafah, tarik ulur antara stigmatisasi dan radikalisme serta sikap pilihan politik antara system khilafah ataupun pilihan politik kebangsaan dalam NKRI. Sehingga subtansi persoalan tersebut dapat dirasionalisasikan dengan menggunakan interpretasi yang sama dan berpijak pada kepentingan bersama (public). Hal ini dapat didasarkan pada sejarah awal dalam perumusan pancasila yang pada saat itu juga dihadapkan pada situasi pro-kontra, meskipun perbedaan ini tidak bisa dipisahkan dari konteks politik dan sosial yang berbeda.

Kontradiksi ini dapat dipahami dengan menggunakan konsep ruang public Habermas, sebab beberapa studi sebelumnya juga pernah memberikan catatan bahwa Ide normatif Habermas tentang diskursus politik dan secara khusus penalaran publik atas tradisi-tradisi religius itu ternyata telah menjadi praxis politik para pendiri bangsa Indonesia di awal kemerdekaan ketika hendak merumuskan dasar negara kesatuan republik Indonesia pada tahun 1945.

Studi ini melihat adanya peluang bahwa demokrasi deliberative dapat dilakukan dalam keadaan terbuka, bahkan disertai perdebatan serius, meskipun masing-masing komunitas menghendaki ideologinya menjadi dasar bernegara Indonesia. Hal itu dapat dilihat kembali bagaimana proses perumusan pancasila pernah terjadi saat itu. Pidato yang lebih dikenal dengan istilah pidato lahirnya pantjasila lahir dari perdebatan yang sengit diantara tiga proponen ideologi yang kuat pada waktu itu, yaitu Nasionalisme kedaerahan (khususnya tradisionalisme Jawa), Islam, dan Marxisme/Sosialisme. Masing-masing ideologi ini bukan hanya sekadar fenomena yang mewarnai pada bulan Mei-Juni 1945 ketika dasar negara dibicarakan, tetapi juga sudah terjadi jauh-jauh hari sebelumnya.

Karena itu, dari proses dialektika tentang ide khilafah yang ditampilkan dalam ruang publik siber ini diharapkan mampu menghasilkan konsensus bersama diantara komunitas keagamaan secara partisipatif, dengan catatan ketika masing-masing komunitas bersedia melakukan deliberasi (pertimbangan) dan penalaran publik atas pandangan-pandangannya. Pengalaman yang terjadi pada awal sejarah dalam berbangsa yang berhasil dalam mewujudkan konsensus bukan hanya dapat terjadi karena kekuatan-kekuatan partikular ideologi yang sedang bersaing, melainkan juga secara khusus banyak ditentukan oleh aspek keagamaan. Karena itu penalaran bagi masing-masing komunitas keagamaan menjadi penting demi tetap terwujudnya kepentingan bersama. 
Kedua, Perdebatan tentang ide khilafah dalam ruang publik siber ini juga dapat menjadi ruang untuk mempertemukan nilai-nilai kemanusiaan sebagai poros orientasi tindakan, dalam hal ini nilainilai agama yang berbeda pemaknaan dimungkinkan untuk dipertemukan dalam upaya mewujudkan kepentingan bersama.

Karena itu, apabila agama ingin memberikan kontribusi terhadap perkembangan demokrasi, maka nilai-nilai etika universal yang ada dalam agama yang dipercayai juga harus berlaku dalam segala tempat dan zaman (sholih likulli zaman wal makan), hal demikian perlu dipahami bersama hingga menjadi habitus bangsa. Karena itu nilai-nilai yang bersumber dalam al-Qur'an yang memiliki afinitas dengan dunia modern tercermin pada nilai wasathiyah (moderasi), tawazun (keseimbangan), tasamuh (toleransi), mahabbah (kasih sayang), ijtima'iyyah (kebersamaan), musawah (persamaan), 'adalah (keadilan), ukhuwah (persaudaraan), dan lainnya yang merupakan nilai-nilai universal yang layak untuk dijadikan diteguhkan kembali dan menjadi referensi bersama.

Sejauh nilai-nilai substansial itu telah dijalankan, maka sesungguhnya tujuan Islam tentangkeadilan, kesetaraan, kebebasan, kemakmuran maka akan dapat terus diperjuangkan, dan selanjutnya bangsa ini dapat dipahami sebagai bangsa yang sesungguhnya telah Islami. Sebab, agama sesungguhnya tidak dapat dikotak sebagai urusan privat, tetapi juga, tidak dapat seluruhnya dipublikkan, jika bertentangan dengan konstitusi. Karena itulah memasukkan nilai-nilai agama dalam ruang public diperbolehkan, sejauh berurusan dengan masalah mu'amalah (perdata). Namun, jika sudah berkaitan dengan hukum pidana, seperti hudud (hukum potong tangan), maka penetapansyari'ah itu batal demi konstitusi.

Dalam konteks ini, agama dan demokrasi menurut hemat peneliti sesungguhnya dapat disandingkan sejauh keduanya dapat saling memberikan ruang yang tidak saling menegasikan. Maka, dalam konteks ini dapat ditegaskan bahwa sesungguhnya antroposentris dapat menjadi landasan orientasi demokrasi dan tidak harus dipertentangkan dengan teosentris yang selalu menjadi rujukan Islamisme. Demokrasi-religius sangat mungkin dihadirkan jika hubungan antara manusia dengan manusia menjadi jalan kesempurnaan menuju hubungan antara manusia dengan tuhannya harus disekutukan.

Artinya kemanusiaan sebagai poros relasi antar manusia telah menjadi pertemuan nilai-nilai universal antara semua agama dengan sekulerisasi. Karena itu, keinginan untuk bisa mewujudkannya, maka dapat dilakukan dengan cara memperluas anjuran yang pernah dipopulerkan oleh $\mathrm{KH}$. Achmad Siddiq yaitu agar tidak terjadi disintegrasi, maka Islam harus mampu merawat tiga ikatan persaudaraan, Yaitu, "ukhuwah Islamiyah" (persaudaraan keIslaman), "ukhuwah wathaniyyah" persaudaraan kebangsaan) dan "ukhuwah basyariyah (persaudaraan kemanusiaan), ikatan persaudaraan ini dapat mencairkan ikatan primordial keagamaan, bahkan dijauhkan dari ancaman disintegrasi bangsa.

Ketiga, perdebatan yang terekspresikan dalam ruang publik siber ini menjadi tantangan yang juga dapat mengkhawatirkan terhadap bangunan demokrasi di Indonesia. Hal ini dapat didasarkan pada tampilan perdebatan yang cukup berkepanjangan, bahkan dalam ekspresi tersebut tidak sekedar diwarnai oleh perdebatan argumentasi yang lebih rasional. Yang nampak adalah benturan anatara komunitas, bahkan diantaranya juga banyak ditandai dengan narasi dan percakapan yang mengandung nada-nada sentiment diantara komunitas keagamaan.

Lihat saja bagaimana tampilan tentang percakapan dan narasi-narasi yang ditampilkan melalui media komunitas keagamaan siber, banyak ditemukan teks-teks yang mengandung arti kebencian, termasuk pesan-pesan yang menunjukkan terhadap penolakan gagasan dari pihak lainnya. Setidaknya dengan ruang publik siber ini dapat terwujud bagaimana mempertemukan corak keagamaan yang skriptualis, tekstualis, yang cenderung menuntut arti pentingnya penyeragaman keyakinan yang eksklusif, intoleran, dengan corak keberagamaan yang inklusif, toleran, moderat, dan terbuka terhadap pembaharuan adalah sesuatu yang tidak mudah terjadi.

Prosesdialektika yang dianggap rumit ini, sesungguhnya membutuhkan adanya kesediaan untuk "meliberalisasi diri" sehingga dapat mempertemukan persamaan daripada membesar-besarkan perbedaan. Terlalu sulit untuk diramalkan jika cara keberagamaan masih berada pada orientasi yang 
serba verbalitas, dimana agama hanya dihampiri sebagai eksekutor realitas, yang serba menghakimi (halal-haram, boleh-tidak boleh) dan bukan sebagai inspirasi untuk mendorong perubahan. Selama kehendak bersama (common platform) yang telah dirumuskan dalam Pancasila gagal diyakini sebagai jalan terbaik, maka hampir dipastikan masa depan demokrasi di Indonesia akan terus terancam oleh siklus konflik horizontal, khususnya akibat politik identitas keagamaan yang bercorak Islamisme.

\section{Kesimpulan}

Berdasarkan uraian data ini, maka dapat disimpulkan bahwa realitas keagamaan dalam media publik siber, yang ditandai dengan munculnya tampilan perdebatan/diskursus tentang khilafah dan politik kebangsaan. Satu sisi melalui media komunitas media dakwah Islam kaffah ide khilafah ini menampilkan paham sebagai ajaran Islam yang diyakini kebenarannya serta harus disampaikan melalui aktifisme dakwah kepada seluruh umat Islam, sehingga hukum-hukum Allah SWT (syariat Islam) dapat diterapkan secara kaffah. Sementara pemahaman ini bertentangan dengan paham komunitas keagamaan lain, salah satunya di ekspresikan melalui media komunitas organisasi NU, yang memberikan pemahaman bahwa khilafah adalah fakta sejarah, sementara keharusan menerapkan system khilafah dinilai bertentangan dengan system politik kebangsaan Indonesia. Studi ini mencatat bahwa media komunitas NU banyak menampilkan narasi-narasi kontra serta memberikan penegasan bahwa system politik kebangsaan yang diikat dalam NKRI adalah Harga Mati, dan tidak bisa ditawartawar lagi. Sementara proses dialektika khilafah dan Ideologi kebangsaan ini ditandai perdebatan/diskursus dalam isu-isu penting menyangkut ide khilafah dan politik kebangsaan, diantaranya perdebatan tentang khilafah yang dipahami sebagai ajaran Islam atau sebagai fakta sejarah, perdebatan antara sebagai wujud stigmatisasi dan radikalisme, serta perdebatan pilihan politik, antara system khilafah atau NKRI harga mati. Studi ini juga berhasil memberikan gambaran bahwa dibalik perdebatan khilafah dan politik kebangsaan sesungguhnya dapat menjadi ruang dalam mempertemukan nilai-nilai kemanusiaan sebagai poros orientasi tindakan, dalam hal ini nilainilai agama yang berbeda pemaknaan sesungguhnya dapat dimungkinkan untuk dipertemukan dalam upaya mewujudkan kepentingan bersama. Meski demikian, perdebatan yang terekspresikan dalam media siber ini juga dapat menjadi tantangan bagi bangunan demokrasi di Indonesia. Hal ini dapat dibuktikan dengan data digital yang menunjukkan bahwa jejak percakapan dan narasi perdebatan ini berlangsung berkepanjangan dengan tidak menunjukkan adanya titik temu. Bahkan tampilannya juga ditandai oleh ekspresi yang saling berbenturan, banyak teks perdebatan mengandung nada-nada sentimen antara komunitas keagamaan. Disinilah penulis menganggap penting adanya penalaran publik dalam lingkungan demokrasi yang sesungguhnya bisa diarahkan pada demokrasi yang deliberatif sebagaimana konsep yang dibangun oleh Habermas dalam setiap proses diskursus khilafah dan politik kebangsaan, meskipun dialektika ini sedang berlangsung dalam media publik siber.

\section{Referensi}

Aguilera-Carnerero, C., \& Azeez, A. H. (2016). 'Islamonausea, not Islamophobia': The many faces of cyber hate speech. Journal of Arab E Muslim Media Research, 9(1), 21-40. https://doi.org/10.1386/jammr.9.1.21_1

Aiken, H. D., \& Djatmiko, S. (2009). Abad ideologi. Yogyakarta: Yayasan Bentang Budaya.

Arifin, S. (2018). Utopia Negara khilafah : Ideologi dan Gerakan Sosial Hizbut Tahrir. Malang: Literasi Nusantara.

Aziz, A. (2019). Kontroversi khilafah. Yogyakarta: LKiS bekerjasama dengan Yayasan Talibuana Nusantara.

Bunt, G. R. (2003). Islam in the digital age: E-jihad, online fatwas and cyber Islamic environments. London: Pluto Press.

Dawson, L. L., \& Cowan, D. E. (2004). Religion Online. In Religion Online: Finding Faith on the Internet. Routledge. https://doi.org/10.4324/9780203497609

Dwivedi, P. S., \& Narula, A. (2020). Religious communities in simulated sacred spaces: A study of pilgrimages in digital media. Journal of Content, Community and Communication, 11(10), $260-267$. https://doi.org/10.31620/JCCC.06.20/19

Faiz, A. (2003). Khilafah adalah Solusi/Anonim. Bogor: Pustaka Tharoqul Izzah.

Fakhruroji, M. (2017). Dakwah di era media baru: Teori dan aktivisme dakwah di internet. Bandung: Simbiosa Rekatama Media. 
Fathoni. (2018). Bersama NU, Muhammadiyah Tegaskan Menolak Paham Khilafah. Retrieved 20 March 2021, from NU Online website: https://www.nu.or.id/post/read/98357/bersama-nu-muhammadiyah-tegaskanmenolak-paham-khilafah

Florentin, V. (2018, April). Azyumardi Azra: HTI Berbahaya bagi Eksistensi Pancasila. Retrieved 14 May 2021, from Tempo website: https://nasional.tempo.co/read/1076709/azyumardi-azra-hti-berbahaya-bagieksistensi-pancasila

Giles, D., Stommel, W., Paulus, T., Lester, J., \& Reed, D. (2015). Microanalysis of Online Data: The Methodological Development of "Digital CA". Discourse, Context $\backslash \mathcal{E}$ Media, 7, 45-51.

Giorgi, A. (2019). Mediatized Catholicism-Minority Voices and Religious Authority in the Digital Sphere. Religions, 10(8), 1-21. https://doi.org/10.3390/rel10080463

Habermas, J. (2015). The Structural Transformation of the Public Sphere: An Inquiry Into a Category of Bourgeois Society. Wiley.

Hardiman, F. B. (2010). Ruang Publik: Melacak Partisipasi Demokratis dari Polis Sampai Cyberspace. Yogyakarta: Pustaka Fisafat.

Hegel, G. W. F., Sibree, J., Friedrich, C. J., \& Hegel, C. (2012). The Philosophy of History. Dover Publications.

Hilmy, M. (2008). Islam profetik: substansiasi nilai-nilai agama dalam ruang publik. Yogyakarta: Kanisius.

Hilmy, M. (2014). Akar-akar Transnasionalisme Islam Hizbut Tahrir Indonesia (HTI). Islamica: Jurnal Studi Keislaman, 6(1), 1-13. https://doi.org/10.15642/islamica.2011.6.1.1-13

Hilmy, M. (2015). Radikalisme Agama dan Politik Demokrasi di Indonesia Pasca-Orde Baru. MIQOT: Jurnal IlmuIlmu Keislaman, 39(2), 407-425. https://doi.org/10.30821/miqot.v39i2.33

Horton, J. (2003). Rawls, Public Reason and the Limits of Liberal Justification. Contemporary Political Theory, 2(1), 5-23. https://doi.org/10.1057/palgrave.cpt.9300070

Hudjolly. (2011). Imagologi : strategi rekayasa teks (M. Sandra, Ed.). Yogyakarta: Ar-Ruzz Media.

Kemala, A. N. (2017). HTI Resmi Dibubarkan Pemerintah Halaman all - Kompas.com.

Kementerian Agama RI. (2019). Moderasi Beragama. Jakarta: Badan Litbang dan Diklat Kementerian Agama RI.

Khilafah Channel. (2019a). 95 Tahun Umat Islam Tanpa Khilafah. Khilafah Channel. Retrieved from https://www.youtube.com/watch?v=1vlJUdaX4RU

Khilafah Channel. (2019b). Benarkah Khilafah Tidak Ada Dalam Al Quran? Retrieved from Khilafah Channel website: https://www.youtube.com/watch?v=Al6byV87X2o

Khilafah Channel. (2020a). 4 Alasan Pentingnya Khilafah - KH Yasin Muthahar. Indonesia. Retrieved from https://www.youtube.com/watch?v=1Q84OI51S4w

Khilafah Channel. (2020b). Kajian Online, Pengertian Khilafah \& Kabar Malam. Khilafah Channel. Retrieved from https://www.youtube.com/watch?v=Hwj6cQb_9GU

Kurnia, A. M. B., Wahid, A., \& Yustika, G. P. (2018). Kontroversi Penerapan Khilafah di Indonesia. Jurnal Islamika: Jurnal Ilmu-Ilmu Keislaman, 18(01), 19-24. https://doi.org/10.32939/islamika.v18i01.241

Lyotard, J. F. (1984). The Postmodern Condition: A Report on Knowledge. University of Minnesota Press.

Meredith, J. (2017). Analysing technological affordances of online interactions using conversation analysis. Journal of Pragmatics, 115, 42-55. https://doi.org/10.1016/j.pragma.2017.03.001

Morissan, Andy Corry Wardhani, Farid Hamid U., R. S. (2013). Teori Komunikasi Massa: Media, Budaya, dan Masyarakat. Ghalia Indonesia.

NU Channel. (2019). (Live) KH. Hasyim Asy'ari Sudah Ma'rifat... Khilafah akan Bubar..!!! Retrieved from https://www.youtube.com/watch?v=kRDzHl6vnmU

NU Online. (2018). Menolak Ide Khilafah di NKRI - Ust. Ahmad Muntaha AM. NU Online. Retrieved from https://www.youtube.com/watch?v=EDOWN3WXg-s

Paulus, T., Warren, A., \& Lester, J. N. (2016). Applying conversation analysis methods to online talk: A literature review. Discourse, Context $\mathcal{E}$ Media, 12, 1-10. https://doi.org/10.1016/j.dcm.2016.04.001

Priyono, A., Samadhi, W. P., \& Tornquist, O. (2005). Menjadikan Demokrasi Bermakna: Masalah dan pilihan di indonesia. Jakarta: Lembaga Kajian Demokrasi dan Hak Asasi.

Rawls, J. (1987). The Idea Of An Overlapping Consensust. Oxford Journal of Legal Studies, 7(1), 1-25. https://doi.org/10.1093/ojls/7.1.1

Rizki, M. F. (2018). Deradikalisasi Pengikut Hizbut Tahrir Indonesia Pasca Terbitnya Perppu No.2 Tahun 2017 Tentang Ormas. Jurnal Politikom Indonesiana, 3(1), 164-176.

Rulli, N. (2014). Teori dan Riset Media Cyber. Surabaya: Kencana.

Sofiuddin. (2017). Gerakan Politik Hizbut Tahrir Indonesia: Mampukah Menjadi Gerakan Dakwah? Jakarta: Pustaka Compass.

Sugihartati, R. S. (2014). Perkembangan Masyarakat Informasi \& Teori Sosial Kontemporer. Surabaya: Kencana.

Tibi, B. (2016). Islami dan Islamisme. Yogyakarta: Mizan. 
TVNU Televisi Nahdlatul Ulama. (2020, February). Ma'rifat Mbah Hasyim Atas Bubarnya Khilafah. TVNU Televisi Nahdlatul Ulama. Retrieved from https://www.youtube.com/watch?v=TYbyFX0CfVk

Virtanen, M. T., \& Kääntä, L. (2018). At The Intersection of Text and Conversation Analysis: Analysing Asynchronous Online Written Interaction. $x x(11)$.

Yusanto, I. (2016). Perjuangan Dengan Dakwah Islam. Yogyakarta: Irtikaz.

Zain, A. (2019). Khilafah Dalam Islam. Al-Idarah: Jurnal Manajemen Dan Administrasi Islam, 3(1), 41-55.

Zakaria, T., Busro, B., \& Furqon, S. (2018). Filter bubble effect and religiosity: filter bubble effect implication in the formation of subjects and views of religiosity. IOP Conference Series: Materials Science and Engineering, 434, 012280. https://doi.org/10.1088/1757-899X/434/1/012280

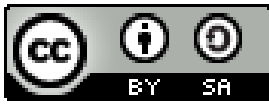

(C) 2021 by the authors. Submitted for possible open access publication under the terms and conditions of the Creative Commons Attribution (CC BY SA) license (https://creativecommons.org/licenses/by-sa/3.0/). 